Prosiding Seminar Nasional Teknologi Informasi dan Kedirgantaraan : Transformasi Teknologi untuk Mendukung Ketahanan Nasional, Yogyakarta, 13 Desember 2018

SENATIK 2018, Vol. IV, ISBN 978-602-52742-0-6

DOI: http://dx.doi.org/10.28989/senatik.v4i0.141

\title{
SYSTEM MODELLING AND DATABASE FOR DOCTOR RESERVATION APPLICATION BASED ON LOCATION Achmad Yusron Arif ${ }^{1}$, Friden Elefri Neno $^{2}$, Henderi ${ }^{3)}$ \\ Magister Teknik Informatika \\ Universitas Amikom Yogyakarta \\ Jl. Ring Road Utara, Condong Catur, Sleman, Yogyakarta \\ Email : ${ }^{1}$ achmad.arif@ students.amikom.ac.id, ${ }^{2}$ friden.neno@ @students.amikom.ac.id, ${ }^{3}$ henderi@mail.ugm.ac.id
}

\begin{abstract}
There are many benefits of using information technology in the health sector such as to make hospital information system, clinic or puskesmas. Now, queuing reservation system is still done manually or just using SMS / by phone, required a system that can be used patient to find and do doctor reservation. Thus, the patient when it comes can be directly checked without having to wait for a long time. Another problem when someone goes to a new area, then need medical services as soon as possible because of that is needed an application which contains information of doctor / clinic nearby. Therefore, in this paper will be discussed draft doctor reservation application by displaying a list of doctors. So the patient simply open the application and will be displayed a list of doctors, this will certainly facilitate the patient in finding and make a doctor reservation.
\end{abstract}

Keyword: system design, doctor reservation, system information, health sis

Abstrak

Ada banyak manfaat penggunaan teknologi informasi di sektor kesehatan seperti untuk membuat sistem informasi rumah sakit, klinik atau puskesmas. Saat ini sistem reservasi antrian masih dilakukan manual atau hanya menggunakan SMS / Telepon, dibutuhkan sebuah sistem yang bisa digunakan pasien untuk mencari dan melakukan reservasi dokter. Sehingga, pasien ketika datang sudah bisa langsung periksa tanpa harus menunggu lama. Masalah lain ketika seseorang pergi ke daerah yang baru, kemudian membutuhkan pelayanan medis secepatnya maka dibutuhkan aplikasi yang berisikan informasi dokter / klinik terdekat. Karena itulah, dalam tulisan ini akan dibahas rancangan aplikasii reservasi dokter dengan menampilkan daftar dokter. Sehingga pasien cukup membuka aplikasi kemudian akan ditampilkan daftar dokter, hal ini tentu akan memudahkan pasien dalam mencari dokter / klinik yang sesuai dengan kebutuhan.

Kata Kuci : rancangan aplikasi, reservasi dokter, sistem informasi, sis kesehatan

\section{Pendahuluan}

Penerapan teknologi informasi di bidang kesehatan, salah satunya pemanfaatan untuk sistem reservasi / pemesanan dokter / klinik. Saat ini masih banyak dokter / klinik yang memberlakukan sistem manual untuk reservasi / pemesanan untuk pelayanan. Sehingga, tidak heran jika calon pasien harus datang pagi-pagi hanya untuk mengambil nomor antrean, dimana praktik dokter masih buka beberapa jam kemudian. Selain itu, jika ada orang yang baru berpergian / pindah ke daerah yang baru dan tiba-tiba membutuhkan pelayanan medis yang cepat maka cukup kesulitan, karena keterbatasan akses informasi untuk mengetahui tempat pelayanan kesehatan terdekat. 
Dengan menggunakan aplikasi khusus yang berisikan daftar dokter / klinik terdekat dari lokasi pasien maka akan sangat memudahkan pasien untuk mendapatkan akses dengan segera, apalagi jika dalam aplikasi tersebut akan ada akses untuk melakukan reservasi / pemesanan. Sehingga pasien ketika datang ke lokasi tidak usah harus menunggu lagi, karena data pasien sudah terdapat dalam sistem admin.

Dalam tulisan ini kami fokus pada perancangan basis data / database, dimulai dari proses normalisasi data hingga perancangan tabel-tabel beserta field yang dibutuhkan beserta dengan relasi antar tabel. Perancangan database ini sangat penting, karena jika terjadi kesalahan atau ketidak efektifitasan dalam membuat rancangan database maka aplikasi bisa mengalami load data yang berlebih, redudansi data, serta akan susah dalam mengembangkan di masa depan. Apalagi jika data yang diolah memiliki record yang besar.

Sample data dokter dan klinik kami dapatkan dari www.data.go.id, dimana website ini adalah website resmi dari Pemerintah Indonesia yang berisikan data-data umum dari kementerian, lembaga ataupun instansi-instansi lainnya. Kemudian data tersebut kita olah dan normalisasi sehingga bisa disusun rancangannya dalam bentuk UML (Unified Modeling Language).

\section{Metodologi Penelitian}

Metodologi yang digunakan dalam penelitian ini adalah dimulai dari identifikasi masalah, dalam hal ini identifikasi mengenai masalah reservasi dokter yang selama ini masih dilakukan secara manual. Kedua melakukan studi pustaka / literatur, dalam tahapan ini dilakukan pencarian literatur-literatur yang berkaitan dengan penelitian. Ketiga melakukan pengumpulan data, dengan cara mencari data resmi dari Pemerintah Republik Indonesia melalui situs https://data.go.id. Keempat melakukan analisis kebutuhan sistem dan perancangan aplikasi, dalam tahap ini dirancang pemodelan proses dengan menggunakan Unified Modeling Language (UML) serta rancangan dasar basis datanya.

\section{Hasil dan Pembahasan}

Sebelum pembuatan program aplikasi tahap yang harus dilakukan sebelumnya adalah perancangan. Dalam tahap ini dilakukan perancangan sistem dan basis datanya. Hal ini penting dilakukan karena jika tidak ada perancangan yang matang dan terstruktur maka aplikasi akan susah untuk dikembangkan di masa yang akan datang, apalagi jika data yang harus diolah sudah kompleks. Metodologi perancangan basis data ialah kumpulan cara-cara yang terstruktur dan terorganisasi untuk merancang basis data, setiap teknik memiliki aturanaturan yang harus dipenuhi dan terurut.

Langkah pertama yaitu melakukan normalisasi data terlebih dahulu, normalisasi ialah teknik dalam database untuk mengelompokkan atribut dari suatu relasi sehingga membentuk sebuah relasi yang efektif dan tidak ada redundansi (kadir, 2009). Redundansi ialah duplikasi data atau data yang sama tetapi disimpan lebih dari satu kali, hal ini sangat tidak efektif karena menyebabkan database menjadi berat. Tabel 1 adalah tabel data tidak normal yang akan dinormalisasi. 
Tabel 1. Tabel Data Tidak Normal

\begin{tabular}{|l|l|l|l|l|}
\hline Nama dokter & Alamat klinik & Pasien & $\begin{array}{l}\text { Tanggal } \\
\text { reservasi }\end{array}$ & Jam \\
\hline Joko Minoyo & $\begin{array}{l}\text { Jl.RE Martadinta RT. 002/ } \\
\text { RW. 010 }\end{array}$ & Antonius Harel & $10 / 10 / 17$ & 18.00 \\
\cline { 2 - 4 } & $\begin{array}{l}\text { Jl. Tanjungraya II (RSU } \\
\text { YARSI) }\end{array}$ & Andre Budi Pratama & $22 / 03 / 18$ & 21.00 \\
\hline Abdul Salam & $\begin{array}{l}\text { Jl. KH. Wahid Hasyim (RS. } \\
\text { St. Antonius) }\end{array}$ & Nani Maryani & $20 / 03 / 18$ & 19.00 \\
\hline $\begin{array}{l}\text { Yustar } \\
\text { Mulyadi }\end{array}$ & $\begin{array}{l}\text { Jl. Sultan Abdurrahman } \\
\text { (RS. Mitra Medika) }\end{array}$ & Achmad Luthfan & $21 / 03 / 18$ & 20.00 \\
\hline
\end{tabular}

Tabel 1 berisikan nama dokter, alamat klinik (alamat praktik dokter), daftar pasien, dan waktu reservasi yang dilakukan oleh pasien. Tabel 1 tersebut akan dilakukan normalisasi sebanyak 3NF dengan hasil akhir seperti tabel 2, 3, 4 dan 5 dibawah.

Tabel 2. Jadwal

\begin{tabular}{|l|l|l|l|l|}
\hline Id Jadwal & Tgl & Jam & ID Dokter & ID Klinik \\
\hline 20001 & $10 / 10 / 17$ & 18.00 & 20001 & 31667 \\
\hline 20002 & $20 / 03 / 18$ & 19.00 & 20002 & 36407 \\
\hline 20003 & $21 / 03 / 18$ & 20.00 & 20003 & 31646 \\
\hline 20004 & $22 / 03 / 18$ & 21.00 & 20004 & 37112 \\
\hline
\end{tabular}

Tabel 3. Data spesialis

\begin{tabular}{|l|l|l|}
\hline Id Spesialis & Spesialis & Id Dokter \\
\hline S1 & Paru-Paru & 20001 \\
\hline S2 & Andrologi & 20002 \\
\hline S3 & Alisurologi & 20003 \\
\hline S4 & Syaraf & 20004 \\
\hline
\end{tabular}

Tabel 4. Dokter

\begin{tabular}{|l|l|l|l|}
\hline Id dokter & Nama Dokter & JK & Nomor Surat Tanda Registrasi \\
\hline 20001 & Joko Minoyo & L & 3511604208077393 \\
\hline 20002 & Abdul Salam & L & 3111604212086419 \\
\hline 20003 & Risa Febriana & L & 3121604211057075 \\
\hline 20004 & Ali F. Siauw & L & 3511806209056392 \\
\hline
\end{tabular}


Tabel 5. Pasien

\begin{tabular}{|l|l|l|l|l|l|}
\hline No & Nama & JK & $\begin{array}{l}\text { Tempat } \\
\text { Lahir }\end{array}$ & $\begin{array}{l}\text { Tanggal } \\
\text { Lahir }\end{array}$ & Alamat \\
\hline 1 & Antonius Harel & L & Bantul & $20 / 01 / 95$ & Jalan Menur, Sambilegi Kidul \\
\hline 2 & Nani Maryani & P & Boyolali & $17 / 11 / 96$ & Jalan Gatak, Pedak \\
\hline 3 & Achmad Luthfan & L & Sleman & $10 / 03 / 04$ & Jalan Magelang Km.17 \\
\hline 4 & Andre Budi Pratama & L & Yogyakarta & $20 / 10 / 90$ & Pringapus \\
\hline 5 & Wulan Rahmawati & P & Bandung & $28 / 11 / 76$ & JL. Srigunting Raya No.1 Bandung \\
\hline
\end{tabular}

Use case diagram ialah alat bantu yang digunakan untuk memperoleh serta menganalisis informasi kebutuhan pengguna, sehingga bisa dibuatkan alur / model sistem aplikasi yang akan dibangun. Use Case diagram yang digunakan dalam penelitian ini terdapat 2 (dua) actor yang terdiri dari Pasien dan Dokter dengan rincian sebagai berikut :

Tabel 6. Tabel Aktor

\begin{tabular}{|l|l|l|}
\hline No & Actor & Hak Akses \\
\hline 1 & Pasien & $\begin{array}{l}\text { Pasien melakukan registrasi setelah registrasi pasien melakukan login dengan } \\
\text { masukan User name dan Password,pasien masukan lokasi dan tampilkan } \\
\text { lokasi dokter klinik dan jarak waktu tempuh dan pilih Data dokter, pilih } \\
\text { jadwal dokter }\end{array}$ \\
\hline 2 & Dokter & Input data dokter, jadwal dokter sehingga pasien mendapat informasi jadwal \\
\hline
\end{tabular}

Penelitian ini hanya dibatasi aktivitasnya yaitu hanya pada pasien dan dokter saja, karena penelitian ini fokus pada rancangan aplikasi terhadap proses reservasi yang dilakukan pasien kepada dokter yang akan dituju. Untuk lebih jelasnya perhatikan gambar 1, secara sederhana proses yang dilakukan yaitu pasien melakukan registrasi terlebih dahulu, kemudian login dengan data yang telah didaftarkan sebelumnya. Setelah itu pasien bisa menentukan lokasi kota dimana akan mencari dokter atau juga bisa digunakan dengan fitur nearby doctor yaitu mencari dokter dengan yang ada disekitar pasien. Setelah mendapatkan daftar dokter beserta dengan lokasi dari pasien (ada informasi jarak dan waktu tempuh ke lokasi dokter), maka pasien bisa melakukan reservasi.

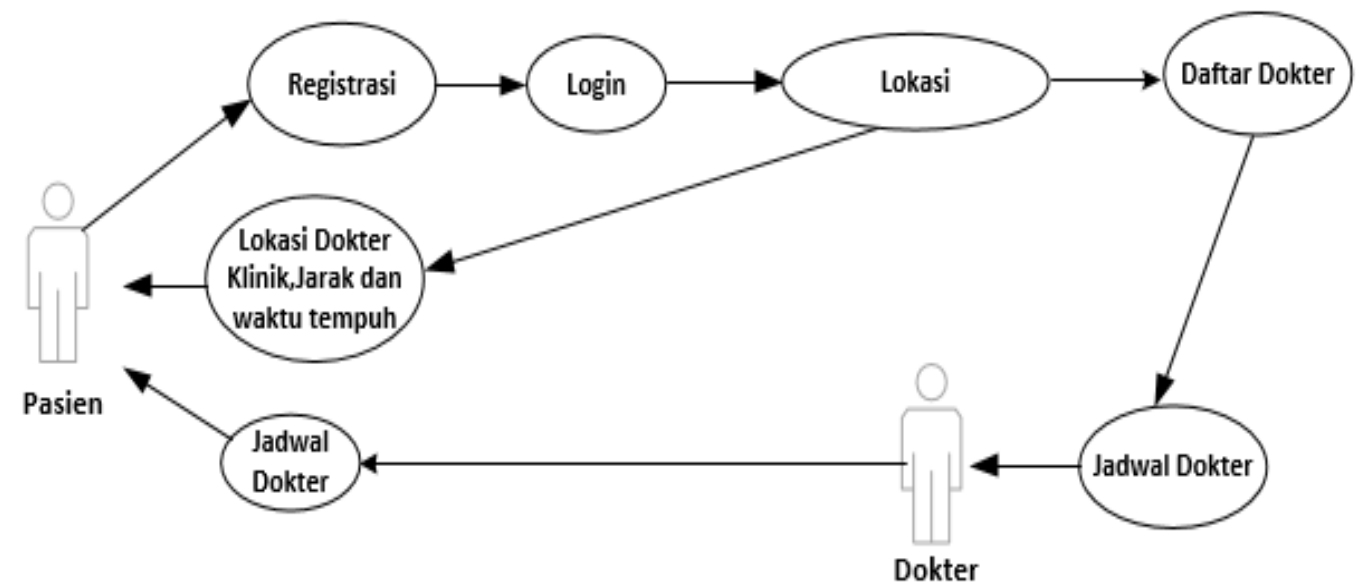

Gambar 1. Use Case Pemesanan Dokter 
Activity diagram ialah bagan yang menggambarkan aliran kerja (workflow) maupun proses bisnis dan aktivitas dari sebuah sistem. Activity diagram dibuat berdasarkan pada use case diagram diatas. Dibawah ini adalah Activity Diagram yang dibuat pada system ini :

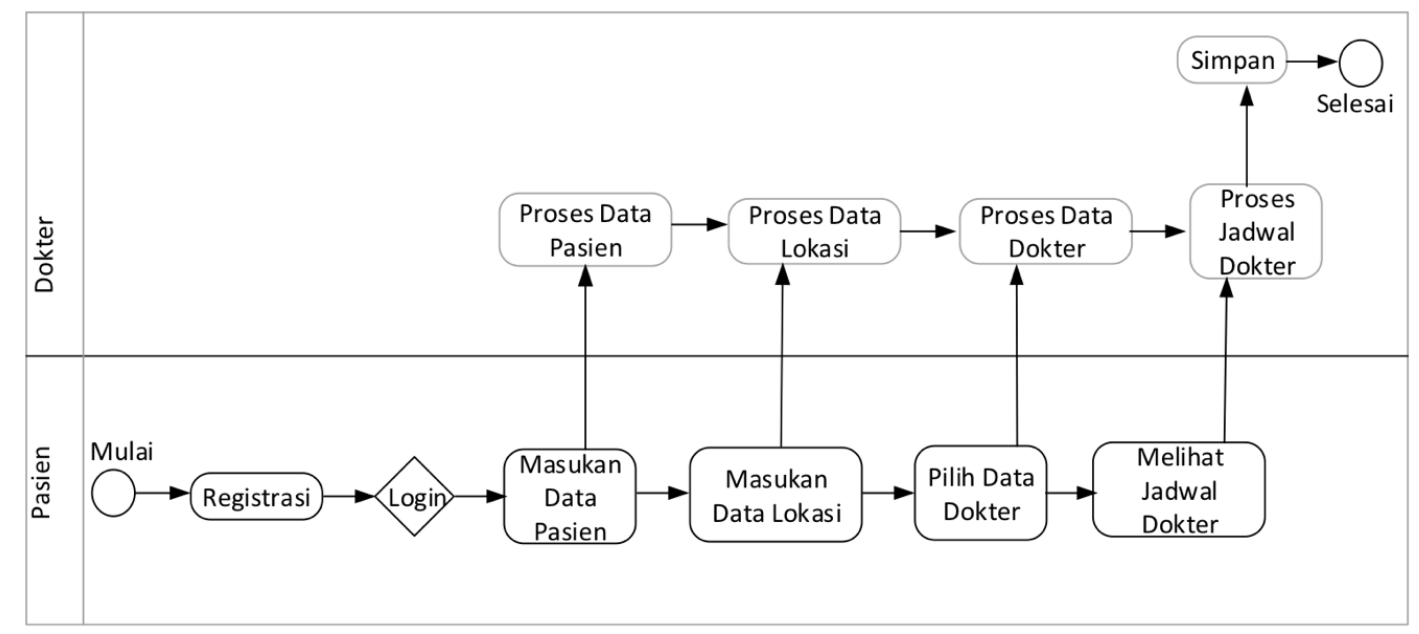

Gambar 2. Activity Diagram Dokter dan Pasien

Aktivitas dimulai dari proses registrasi yang dilakukan oleh pasien dengan memasukkan data diri seperti nama, alamat, no hp dan password. Setelah itu pasien melakukan login dengan menggunakan data diri yang telah diisi sebelumnya. Pada saat proses login dilakukan, aplikasi secara otomatis mendeteksi lokasi dimana pasien berada dengan menggunakan fitur Global Positioning System (GPS) yang sudah ada di smartphone pasien. Pasien sudah bisa mencari dokter yang ingin dituju, data yang ditampilkan dalam bentuk daftar / list dan dalam bentuk peta. Ditampilkan juga informasi mengenai jarak antara lokasi dokter dengan pasien dan estimasi waktu tempuh yang dibutuhkan. Kedua informasi ini penting, mengingat pasien yang sakit harus segera mendapatkan perawatan yang optimal apalgi jika dalam keadaan gawat darurat (emergency).

Sequence diagram adalah bagan yang menggambarkan aktivitas objek pada use case dengan mendeskripsikan aktivitasnya yang dikirimkan dan diterima antar objek. Sequence Diagram Pasien berguna untuk mengetahui proses yang dilakukan Pasien pada system ini. Berikut adalah gambaran Sequence Diagram Pasien pada system yang dibuat: 


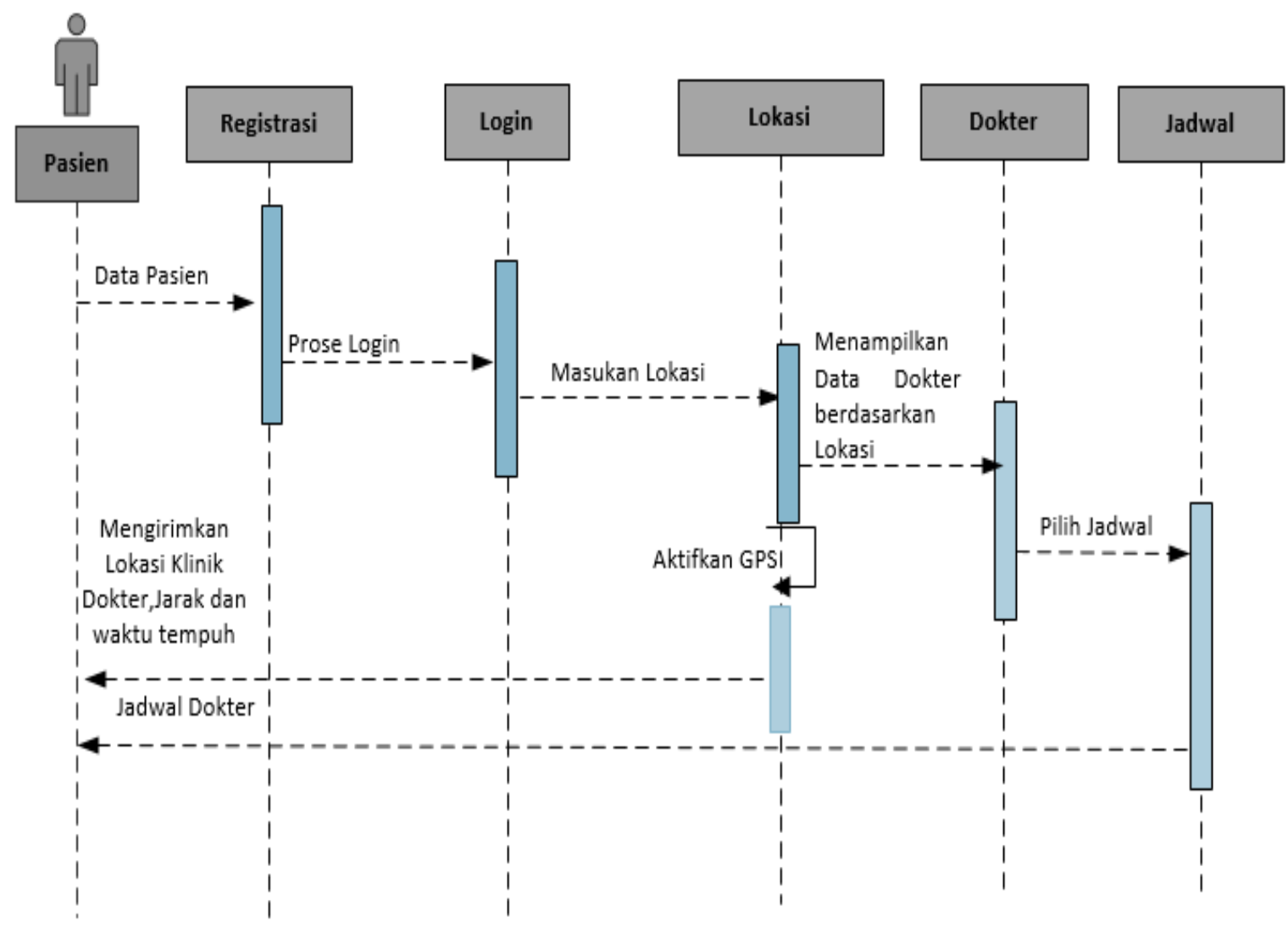

Gambar 3. Sequence Diagram Pasien

Sequence Diagram pasien di atas menggambarkan skenario atau rangkaian langkahlangkah yang dilakukan dalam sistem yang berhubungan dengan Pasien, Alur ini dimulai saat Pasien melakukan registrasi berdasarkan data pasien dan akan mendapat user name dan Password untuk login, lalu pasien masukan data lokasi dan melihat data dokter dan jadwal dokter, selanjutnya pasien mendapatkan data dokter, Klik dokter dan Jadwal dokter Sequence Diagram Dokter berguna untuk mengetahui proses yang dilakukan dokter pada system ini. 


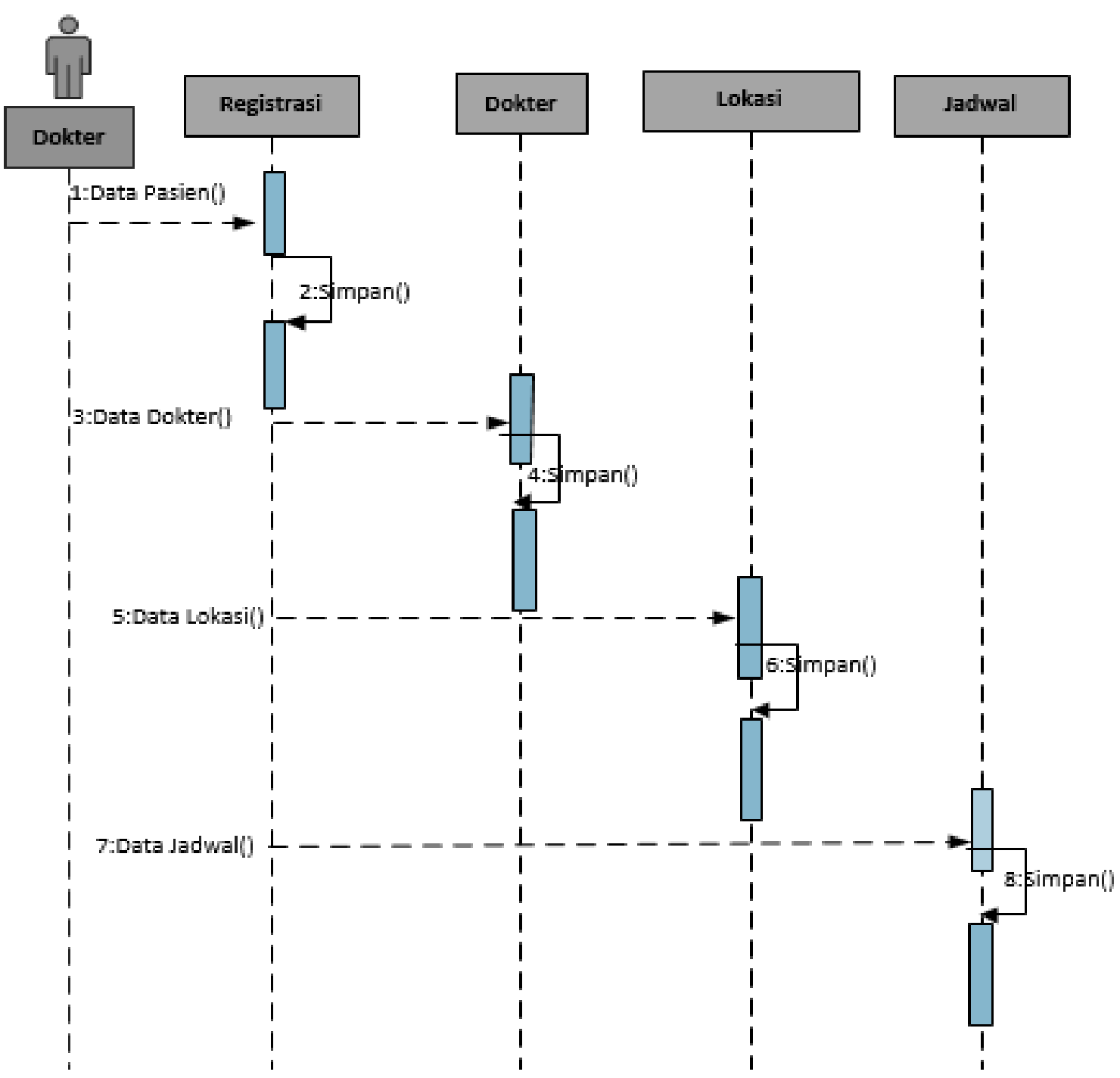

Gambar 4. Sequence Diagram Dokter

Sequence Diagram di atas menggambarkan skenario atau rangkaian langkah-langkah yang dilakukan dalam sistem yang berhubungan dengan Dokter, alur ini dimulai pada saat pasien melakukan pendaftaran berdasarkan data pasien dan menyimpan pada tabel pasien, kemudian dokter akan menginputkan data dokter dan tersimpan pada tabel dokter kemudian system akan memproses sesuai dengan kebutuhan dokter. Langkah terakhit yaitu membuat classs diagram. Class Diagram adalah kumpulan objek-objek yang mempunyai struktur umum, behavior umum, relasi umum, dan semantic/ kata yang umum.

Class diagram didesain memiliki sembilan class yaitu Pasien, dokter,spesialis, klinik,appointment,jadwal,propinsi kabupaten,lokasi. Masing-masing class mewakili datadata yang akan diolah sistem dan saling relasi berdasarkan kata kunci masing-masing yang terdiri dari field kunci utama (Primary Key), yaitu kata kunci yang berada pada class sendiri dan ketika field kunci utama (Primary Key) direlasikan ke class lain diistilahkan kunci tamu (Foregn Key). Class diagram terdiri dari beberapa Tabel master dan transaksi. Berikut table master terdiri dari Propinsi, kabupaten, spesialis dan lokasi table transaksi terdiri dari dokter, pasien,klinik,appointment, dari table master dan transaksi saling relasi dan mengasilkan satu kesatuan sistem. Berikut gambar Class Diagram dibahwa ini: 


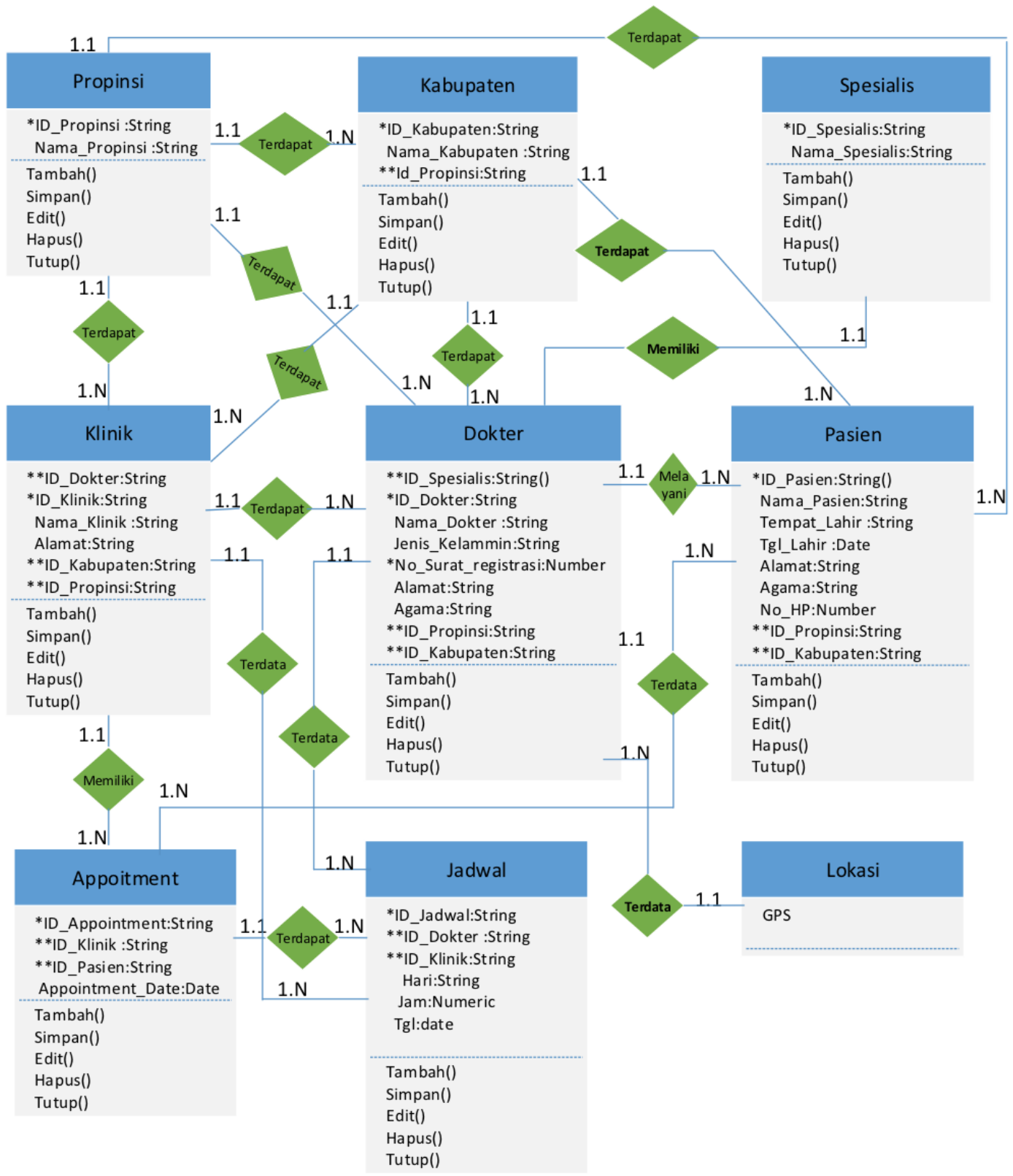

Gambar 5. Class Diagram

\section{Keterangan:}

1.1 ke 1.N= Relasi dari satu ke Banyak

1.N Ke 1.N= Relasi dari banyak ke banyak

* Field Kunci Utama

**Field kunci Tamu atau penghubung

Class / table klinik memiliki beragregasi dengan class dokter alasanya karena klinik dapat berdiri sendiri tanpa ada dokter tidak ada pemesanan pasien. Banyak dokter dapat melakukan pemesanan pasien pada satu klinik . Class/ table Spesialis beragregasi dengan class dokter alasanya karena spesialis berdiri sendiri tanpa ada dokter tidak ada dokter spesialis, satu spesialis terdapat dapat banyak dokter. Tabel lokasi relasi dengan table dokter 
dan dokter relasi dengan jadwal dan table dokter dengan klinik dan appointment dengan alasan tanpa empat table relasi pasien tidak dapat mengakses informasi jadwal dan lokasi

\section{Kesimpulan}

Aplikasi ini bisa memberi jembatan kepada dokter untuk lebih meningkatkan pelayanan yang optimal kepada pasien dalam hal reservasi dokter. Dalam aplikasi ini menampilkan informasi mengenai lokasi dokter, jadwal praktik dokter, dan status reservasi. Kelebihan aplikasi ini ialah, pasien bisa memilih dokter yang akan dituju dengan mudah, bisa berdasarkan spesialis dokter maupun lokasi yang paling dekat dengan pasien.

Saran kepada penelitian selanjutnya adalah supaya dikembangkan sistem untuk follow up pasien, sehingga dokter bisa memantau kesehatan pasien dari jarak jauh. Selain itu juga bisa dikembangkan sistem payment untuk mengurangi reservasi pasif dari pasien atau orang yang tidak bertanggung jawab.

\section{Daftar Pustaka}

[1] Gat, G. (2015). Perancangan Basis Data Perputakaan Sekolah dengan Menerapkan Model Data Relasional. Creative Information Technology Journal, 2(4), 304-315.

[2] Ladjamudin, bin Al-Bahra, (2005) Analisis dan Desain Sistem Informasi. Yogyakarta : Penerbit Graha Ilmu.

[3] Suryasari., Astrid, C., Juwita, S. (2011). Rancangan Aplikasi Customer Service Pada PT. Lancar Makmur Bersama. KNTIA, C39-C42.

[4] Latief, M. (2012). Pendekatan Database untuk Manajemen Data dalam Meningkatkan Kemampuan Mahasiswa Mengaplikasikan Konsep Basisdata. Seminar Internasional, ISSN 1907-2066, 231-238

[5] Simaremare, Yosua P.W., Apol, P., Radityo ,P Wibowo. (2013). Perancangan dan Pembuatan Aplikasi Manajemen Publikasi Ilmiah Berbasis Online pada Jurnal SISFO. JURNAL TEKNIK POMITS Vol. 2, No. 3, A470 - A-475

[6] Setiady, H. (2013). Sistem Informasi Pemesanan Dan Penjualan Berbasis Web Pada Dewi Florist. STMIK GI MDP, 1-7 